KONSTRUKSI KONSUMEN MUSLIM Jurnal Analisa Sosiologi

TERHADAP LABELING HALAL April 2020, 9(1): 197-211 (STUDI FENOMENOLOGI

PENGGUNAAN KOSMETIK HALAL

\title{
DI KALANGAN MAHASISWA
}

\section{POLITEKNIK NEGERI MALANG)}

\author{
Nabeta De Nastiti ${ }^{1}$, Luhung Achmad Perguna ${ }^{2}$
}

\begin{abstract}
The role of the hijrah movement has implications for the manufacture of cosmetic products that are labeled halal. This study aims to determine the social construction of Muslim consumers on halal labeled cosmetic products. The theory used is Peter L. Berger's social construction theory which contains three stages of construction namely internalization, objectification, and externalization. The method in this research is to use a qualitative method with a phenomenological approach. The findings of this research are that the halal label found on cosmetic products is only considered as a sedative and has its own 'plus value' for consumers and halal labeling becomes a symbolic representation of Islam. An externalization process took place in the form of consumer implications considering cosmetic products labeled as halal as a form of symbolic representation of Islam. The objectification process was marked by changes in behavior that were more selective in using cosmetic products (the halal label listed in cosmetics was preferred), the internalization process with the influence of environmental factors (friends of informants) who use cosmetic products labeled as halal so that it affects consumers' decisions to buy cosmetics products that are labeled as halal.
\end{abstract}

Keywords: Islam; Commodity; Halal; Construction.

\begin{abstract}
Abstrak
\footnotetext{
${ }^{1,2}$ Program Studi Pendidikan Sosiologi Universitas Negeri Malang

'nabetade2@gmail.com
}

Peran gerakan hijrah berimplikasi pada pembuatan produk kosmetik yang diberi label halal. Penelitian ini memiliki tujuan untuk mengetahui konstruksi sosial konsumen muslim terhadap produk kosmetik berlabel halal. Teori yang digunakan adalah teori konstruksi sosial miliki Peter L. Berger yang memuat tiga tahapan konstruksi yaitu internalisasi, objektifikasi, dan eksternalisasi. Metode di dalam penelitian ini adalah menggunakan metode kualitatif dengan pendekatan fenomenologi. Adapun hasil temuan dari penelitian ini adalah label halal yang ditemukan pada produk kosmetik hanya dianggap sebagai penenang dan memiliki "nilai plus' tersendiri bagi konsumen serta labelling halal menjadi sebuah 
representasi simbolik Islam. Terjadi proses eksternalisasi berupa implikasi konsumen mempertimbangkan produk kosmetik berlabel halal sebagai bentuk representasi simbolik Islam, Proses objektifikasi ditandai dengan perubahan perilaku yang lebih selektif lagi dalam menggunakan produk kosmetik (label halal yang tercantum dalam kosmetik lebih diutamakan), Proses internalisasi dengan adanya faktor pengaruh dari lingkungan (temanteman informan) yang menggunakan produk kosmetik berlabel halal sehingga mempengaruhi keputusan konsumen untuk membeli produk kosmetik berlabel halal.

Kata kunci : Islam; Komoditas; Halal; Konstruksi.

\section{PENDAHULUAN}

Indonesia adalah negara dengan penduduknya yang mayoritas beragama Islam. Berdasarkan data dari Globalreligiousfuture, jumlah penduduk muslim di Indonesia pada tahun 2010 mencapai 209,12 juta atau setara dengan $87 \%$ dari jumlah populasi. Pada tahun 2020, jumlah penduduk muslim di Indonesia diperkirakan mencapai 229,62 juta jiwa, (katadata.co.id, 2019). Oleh sebab itu, tidak heran jika dalam kehidupannya banyak masyarakat yang sangat memegang teguh nilai-nilai Islam. Beberapa tahun belakangan, fenomena hijrah sedang 'naik daun' di kalangan masyarakat, mulai dari anak muda hingga orang dewasa. Hijrah adalah perubahan kualitas diri yang dilakukan oleh individu maupun kelompok ke arah yang lebih baik secara Islam, dengan tidak meninggalkan ketentuan syariat secara lahiriah maupun batiniah dan menjauhkan diri dari segala larangan Allah secara konsisten, (Aswadi, 2011, dalam Fajriani, 2019). Banyak dari masyarakat melakukan perubahan penampilan secara lebih islami seperti perempuan yang menggunakan hijab, menumbuhkan jenggot bagi kaum laki-laki, hingga kajian-kajian dakwah yang mulai marak dilakukan di media sosial.

Gerakan hijrah yang ramai dilakukan masyarakat ini adalah bentuk 'penasaran' masyarakat karena mereka mulai membuka mata terhadap agama Islam dan ingin mempelajari lebih dalam nilai-nilai Islam. Hijrah yang dilakukan masyarakat berdampak baik karena ini adalah salah satu cara masyarakat untuk selalu mencintai Islam di tengah modernisasi yang berkembang pesat. Hakikat hijrah adalah tranformasi, spiritual serta reformasi sosial sehingga mampu melakukan kehidupan yang lebih baik 
secara personal maupun komunal dengan dinamika kehidupan yang lebih optiman sehingga masyarakat bisa mengahdapi tantangan dalam kehidupan, (Ibrohim, 2016). Minat masyarakat yang begitu tinggi terhadap trend hijrah ini menyebabkan berdirinya komunitas Islam yang mengedukasi semua kalangan masyarakat untuk meninggalkan kebiasaan buruknya di masa lalu dan mulai mendekatkan diri kepada Tuhan-nya. Komunitas Islam ini memiliki misi religious yaitu mengajak masyarakat untuk mencoba meninggalkan kenikmatan duniawi yang fana secara perlahan, dimana halhal duniawi adalah pencapaian utama masyarakat dalam kehidupannya.

Gerakan hijrah juga berpengaruh terhadap pembangunan dan perekonomian negara terutama di bidang industry barang dan jasa. Momentum hijrah ini mulai dimanfaatkan oleh kaum kapitalis dalam memasarkan produknya. Dalam pengimplikasiannya, para pemilik perusahaan berusaha menjual produk mereka dengan menggunakan 'branding islami'. Branding islami yang dimaksud adalah pemberian label halal pada beberapa produk yang sejatinya bukan produk makanan atau bukan produk yang dikonsumsi secara langsung oleh tubuh. Menurut Stanton dalam Suryani (2008), label adalah informasi verbal tentang suatu produk ataupun penjualnya (dalam Putri, 2016). Bagian label bisa dilihat pada kemasan maupun tanda pengenal yang ada di dalam kemasan dalam produk. Sedangkan, halal adalah sesuatu yang diperbolehkan oleh agama baik bersifat sunnah, makruh (harus ditinggalkan), mubah (netral), dan anjuran untuk dilakukan, (Ilyas, 2018).

Salah satu contoh komoditi produk yang diberi label halal adalah produk kosmetik. Labelisasi halal ini ternyata mampu mencuri pasar dan mempengaruhi minat masyarakat dalam membeli produk tersebut (Bulan, T. P. L. 2016).. Masyarakat beranggapan bahwa sertifikasi dalam kehalalan dan labelisasi halal sangat berpengaruh untuk melindungi konsumen dari bahan-bahan yang berbahaya dan diharamkan oleh Islam. Bagi konsumen, sertifikasi dan labelisasi sudah melalui proses uji laboratorium yang sangat panjang dan rinci serta sesuai dengan kaidah syariat yang sesuai Islam sehingga mereka merasa aman dan tidak perlu khawatir akan kandungankandungan dari produk kosmetik yang digunakan. Semakin baik pemahaman agama yang dimiliki maka membuat masyarakat semakin 
selektif dalam membeli produk yang mereka butuhkan. (Widyaningrum, 2017)

Kota Malang adalah kota terbesar kedua di Jawa Timur setelah Surabaya. Kota yang terkenal akan Kota Pendidikan ini terus mengalami perkembangan ekonomi yang sangat pesat setiap tahunnya. Hal ini sejalan dengan tingginya survei nilai konsumsi biaya hidup. Tahun 2019, nilai konsumsi masyarakat Malang mencapai lebih dari 5 miliar (Malangtimes, 2019). Ini berarti menunjukkan bahwa pertumbuhan ekonomi semakin maju, penduduk semakin sejahtera, dan jumlah komoditi berkembang pesat. Hal ini menandakan bahwa peluang pemasaran produk seperti kosmetik juga mengalami kenaikan karena semakin banyaknya peminat produk kosmetik utamanya bagi kaum hawa. Kemudahan pemasaran produk kosmetik ini mampu mendapatkan perhatian konsumen terlebih jika produk kosmetik tersebut disertai dengan label halal. Secara tidak langsung, labelling halal ini membentuk sebuah konstruksi sosial kepada konsumen muslim yang memakai produk tersebut.

Pencantuman labelling halal memang berpengaruh terhadap keputusan konsumen untuk membeli produk tersebut baik produk makanan maupun kosmetik (Nugraha, 2017 dan Khomariyah, 2016). Pemberian label halal pada suatu produk berpengaruh signifikan terhadap minat beli konsumen. Hal ini berarti menunjukkan bahwa konsumen sangat tertarik pada labelisasi halal yang terdapat pada suatu barang. Dengan adanya pemeberian labelisasi halal ini membuat suatu pola yang dilakukan oleh konsumen secara terus menerus dan berkelanjutan. Penelitian lain menunjukkan bahwa minat konsumen untuk membeli suatu produk menjadi tinggi karena didasarkan pada kesadaran konsumen tentang makna halal tetapi pemberian label halal pada suatu produk tidak mempengaruhi keputusan konsumen untuk membeli produk makanan. Maksudnya adalah ada atau tidaknya label halal pada produk makanan, konsumen akan tetap membeli produk tersebut jika mereka mau (Izzudin, 2018). Adapun makna halal dari persepsi produsen makanan adalah halal sangat erat kaitannya dengan konsep Islam yaitu dengan tidak mengandung unsur yang tidak diperbolehkan seperti babi dan alcohol serta tidak merugikan banyak pihak (Muhammad, 2009). Namun, label halal yang tertera pada suatu produk 
belum menjamin pembeli untuk memperoleh haknya sebagai konsumen yaitu jaminan perlindungan hukum terutama konsumen muslim karena masih banyak oknum-oknum produsen yang mencantumkan label halal tanpa melalui sertifikasi dari lembaga LPPOM MUI (Muslimah, 2017). Belum adanya regulasi yang tepat dari lembaga hokum menyebabkan makna halal menjadi polemic di masyarakat. Sebagian peranan MUI bagian administrasi serta auditnya akan diambil alih oleh pihak BPJPH, sehingga MUI hanya berperan sebagai pemberi dan pelaksana sertifikasi halal (Cahyono, 2016).

Berdasarkan permasalahan tersebut, maka fokus penelitian ini terletak pada konstruksi konsumen muslim utamanya mahasiswa sebagai pengguna produk kosmetik berlabel halal. Penelitian ini dinilai penting karena menindaklanjuti efek dari gerakan hijrah yang sedang ramai dilakukan sehingga berakibat pada konstruksi yang dibangun masyarakat terhadap munculnya labelling halal yang disertakan pada produk kosmetik. Penelitian ini memilih informan dengan karakteristik mahasiswi muslim yang menggunakan produk kosmetik berlabel halal utamanya di Politeknik Negeri Malang.

\section{METODE PENELITIAN}

Metode yang digunakan dalam melakukan penelitian ini adalah metode kualitatif dengan pendekatan fenomenologi. Menurut J. Moleong (2013:15), fenomenologi adalah cara pandang atau cara berfikir yang berfokus pada pengalaman-pengalaman subjektif dan interpretasi manusia terhadap dunia. Sedangkan, menurut Husserl fenomenologi diartikan sebagai pengalaman subjektif atau pengalaman fenomenologikal serta studi tentang kesadaran mengenai persepsi seseorang. Lebih khusus lagi, fenomenologi mengacu pada penelitian terdisiplin tentang kesadaran dari perspektif pertama seseorang. Pendekatan fenomenologi adalah pendekatan yang bertujuan untuk mengungkap makna di balik suatu fenomena baik yang terlihat maupun yang tidak terlihat. Peneliti berupaya untuk bisa masuk dan memahami dunia informan (pemikiran dan pemahaman subyektif informan) sehingga peneliti bisa mengetahui hasil dari pola pikir 
informan yang menghasilkan tindakan dan dilakukan sehari-hari (peneliti menekankan aspek subjektif perilaku informan). Adapun karakteristik dalam penentuan informan adalah mahasiswi aktif di Kota Malang, beragama Islam, serta pengguna kosmetik berlabel halal. Teknik wawancara yang dilakukan peneliti adalah 'ngobrol santai' dengan informan di tempat ngopi. Ngobrol santai dilakukan dengan suasana yang informal dilakukan oleh peneliti agar mengenal lebih dalam karakter informan dengan membangun suasana yang lebih santai dengan harapan agar informasi yang didapatkan lebih banyak dan detail. Wawancara dilakukan dengan maksud tertentu untuk mengetahui kondisi sesungguhnya dalam penelitian. Selain itu, peneliti juga merekam hasil wawancara agar informasi yang disampaikan oleh informan tidak sampai terlewat untuk menjadikan sebuah data riil yang ditulis dalam artikel ini. Peneliti juga melakukan observasi partisipatif kepada informan. Observasi dilakukan langsung oleh peneliti secara langsung dan tidak bisa diwakilkan karena peneliti harus melakukan pengamatan mendalam untuk mengetahui gambaran atau kondisi umum antara informan dan lingkungannya (Creswell dalam Moleong, 2013). Peneliti mendatangi kost mahasiswi tersebut untuk melihat sekaligus mendalami mahasiswi pengguna kosmetik halal tersebut. Informan yang dipilih menggunakan teknik purposive. Dalam arti bahwa informan tersebut dianggap peneliti yang paling mengetahui tentang penggunaan kosmetik halal tersebut dilihat dari penggunaan kosmetik sekaligus atribut halal lainnya. Selain menggunakan metode wawancara, peneliti juga tidak lupa untuk mendokumentasikan proses wawancara dengan mengambil foto bersama informan. Dokumentasi foto dijadikan sebagai bukti pendukung bahwa peneliti benar-benar mencari data ke lapangan dan melakukan penelitian.

\section{HASIL DAN PEMBAHASAN}

\section{Hasil}

\section{Label Halal 'Added Value' Bagi Konsumen Hanya Sebagai Penenang}

Di era modern seperti sekarang, masyarakat sudah mulai kritis terhadap produk yang mereka konsumsi dan gunakan seperti pada makanan 
dan produk kosmetik. Masyarakat sudah mulai pintar dalam memilih dan memilah mana produk yang aman untuk mereka pakai dan yang tidak layak untuk digunakan. Kesadaran inilah yang membuat konsumen untuk lebih berhati-hati dalam penggunaan suatu produk. Sehingga, tidak jarang banyak konsumen yang mulai mempertanyakan tentang labelling halal atas suatu produk Vanany, I.,et.al. 2019). . Hal ini tidak terlepas dari peningkatan gaya hidup yang berorientasi pada modernitas dengan diselipi oleh nilai-nilai Islam. Oleh sebab itu, para produsen berusaha untuk mencari peluang pasar dengan membuat suatu produk yang mampu mencuri minat masyarakat. Kekuatan branding inilah yang kemudian membuat suatu konstruksi di kalangan masyarakat. Hal ini sesuai dengan teori yang dipaparkan oleh Peter L. Berger mengenai konstruksi sosial yaitu masyarakat sebagai produk manusia dan juga sebaliknya. Kedua hal tersebut tentu saling berkaitan dan tidak bisa dipisahkan karena apa yang dibutuhkan masyarakat kemudian menciptakan sesuatu yang baru sehingga konstruksi muncul sebagai akibat dari realitas masyarakat.

Masyarakat beranggapan bahwa produk yang sudah terdapat labelling halal berarti produk itu sudah terverifikasi oleh lembaga yang terpercaya dan aman untuk digunakan. Konsumen mempercayai bahwa dalam pembuatannya, produk kosmetik tersebut memiliki kandungan bahanbahan yang tidak membahayakan, tidak dilarang dan tidak haram bagi Islam. Namun, prinsip-prinsip Islam yang mereka pegang ini ternyata tidak sepenuhnya melekat pada diri mereka. Pada realitanya, meskipun labelling halal produk kosmetik ini dianggap penting, mereka masih memungkinkan untuk membeli produk kosmetik lain yang tidak memiliki label halal. Apalagi, jika produk kosmetik tidak berlabel halal tersebut cocok diaplikasikan pada kulit konsumen. Secara tidak langsung label halal bagi konsumen hanyalah sebuah 'nilai plus' tersendiri.

Nilai plus dalam label halal yang dikonstruksikan masyarakat ini sesuai dengan teori konstruksi sosial dari Peter L.Berger, dimana realitas kehidupan manusia memiliki dua dimensi yaitu subyektif dan obyektif. Realitas subyektif diperoleh dari proses internalisasi dimana realitas didasarkan pada pemahaman individu itu sendiri secara sadar sehingga setiap individu memiliki penilaiannya masing-masing terhadap pentingnya 
labelling halal ini. Sedangkan, realitas obyektif ini didapatkan dari proses eksternalisasi atau proses dari luar individu yaitu lingkungan sekitar. Proses eksternalisasi dari labelling halal produk kosmetik ini bisa dilihat dari keseluruhan masyarakat yang membangun pemahaman bahwa produk kosmetik yang memiliki label halal sudah terbukti dan terjamin kualitasnya, yang kemudian disepakati oleh mayoritas konsumen. Konstruksi yang disepakati ini kemudian membentuk suatu pola yang terstruktur. Label halal pada produk kosmetik dianggap sebagai penenang bagi konsumen untuk meyakinkan diri bahwa produk yang mereka gunakan tidak berbahaya bagi diri mereka. Dengan adanya label halal ini, konsumen menghilangkan keraguan atas produk kosmetik tersebut dan merasa terjamin dengan sertifikasi halal yang diberikan LPPOM MUI.

\section{Pembahasan}

\section{Representasi Simbolik dalam Kosmetik X Berlabel Halal}

Dalam perkembangannya, dunia akan selalu bergerak secara dinamis dan selalu berubah secara terus menerus. Perubahan ini kemudian mempengaruhi pada apa yang dibutuhkan manusia terhadap kebutuhan hidupnya. Tentu saja, peran kapitalis sangat melekat pada dunia modernitas ini. Produsen akan melihat realitas masyarakat yang kemudian diimplementasikan pada pembuatan produk yang sesuai dengan keinginan konsumen. Modernitas dunia akan mempengaruhi pada gaya hidup manusia, terlebih lagi sekarang banyak konsumen yang melihat suatu produk berdasarkan ketentuan dari ajaran-ajaran Islam. Label halal yang diterapkan pada produk kosmetik adalah salah satu contoh bahwa nilai-nilai Islam sangat erat dibutuhkan pada konsumen. Masuknya nilai-nilai Islam ini kemudian membentuk suatu konstruksi terhadap konsumen muslim produk kosmetik atas suatu realitas.

Dari hasil penelitian, didapatkan konstruksi sosial dimana konsumen muslim menganggap bahwa label halal yang terdapat di produk kosmetik sebagai bentuk dari representasi simbolik Islam. Representasi adalah suatu keadaan atau proses sosial yang berhubungan dengan konsep atau budaya masyarakat di suatu tempat. Menurut KBBI, representasi sendiri adalah suatu sikap perwakilan dari sekelompok orang pada suatu lingkungan 
tempat tinggal (KBBI, 2012-2019). Representasi simbolik Islam ini didasarkan pada kaidah Islam yang telah ditetapkan sehingga konsumen merasa aman karena tidak melanggar ketentuan syariat (ketentuan Islam yang dimaksud adalah kandungan bahan yang ada pada produk kosmetik harus terjamin, aman dan tidak haram digunakan). Bagi konsumen pemberian label halal penting dilakukan karena sejak kecil mereka telah belajar Islam sehingga mereka menganggap label halal harus diberikan tidak hanya pada produk makanan atau produk yang bisa dikonsumsi saja melainkan pada produk kosmetik juga meskipun penggunaannya hanya dioles di luar tubuh sebagai nutrisi kulit. Pengetahuan ilmu agama Islam ini kemudian direpresentasikan oleh masyarakat muslim kepada produk kosmetik sebagai symbol bahwa Islam mengatur hal sekecil apapun untuk kebaikan mereka. Mereka akan merasa tenang jika mengikuti aturan dan larangan yang ditetapkan Islam karena apa yang sudah diatur tidak mungkin memberikan dampak buruk bagi tubuh mereka.

Sikap konsumen dalam menentukan produk kosmetik berlabel halal berdasarkan pengetahuan atau ajaran Islam yang didapatkan sejak kecil dari lembaga (keluarga) ini, sesuai dengan teori kosntruksi Peter L. Berger, dimana implikasi penentuan sikap konsumen dalam memilih produk kosmetik halal berasal dari sosialisasi sekunder. Selain itu, label halal produk kosmetik juga disosialisasikan dari lembaga MUI yang memberikan sertifikasi halal dan lulus uji. Kehadiran lembaga-lembaga yang terpercaya ini, kemudian membuat masyarakat merasa bahwa umat muslim perlu mendapatkan 'perlakuan khusus' pada produk yang dipasarkan terutama tentang halal dan haramnya sesuatu. Masyarakat muslim tidak bisa serta merta untuk langsung menerima semua produk yang beredar karena apa yang mereka konsumsi maupun pakai harus jelas kehalalannya tentang bahan yang terkandung dalam kosmetik tersebut. Panjangnya proses kehalalan suatu produk sebelum diproduksi ini membuat konsumen mengkonstruksikan bahwa label halal adalah symbol Islam untuk mengatur umatnya sebelum menggunakan produk yang mereka beli. Sehingga, label halal ini berkonsep untuk menghargai aturan Islam bahwa dalam pembuatan produk tidak boleh menggunakan bahan yang dilarang dalam Islam. Oleh sebab itu, keberadaan label halal ini, diperlukan oleh konsumen untuk 
meminimalisir produk-produk di pasaran yang tidak sesuai dengan kaidah Islam.

Hasil pemikiran dan pemahaman konsumen yang akhirnya melahirkan suatu pola dalam menggunakan kosmetik halal terbentuk melalui beberapa proses sehingga menghasilkan suatu konstruksi. Perilaku masyarakat yang menghasilkan suatu konstruk mengenai label halal didasarakan pada pengalaman subyektif informan yang dipengaruhi oleh beberapa faktor seperti faktor agama dan faktor lingkungan. Faktor agama yang dimaksud adalah berupa ilmu yang didapatkan konsumen mengenai kaidah halal dan haramnya sesuatu. Pengajaran Islam ini didapatkan sejak masih anak-anak dari orang tua dan guru sehingga mereka mencoba mengimplementasikan keislaman mereka melalui sebuah perubahan pola perilaku. Implementasi yang dilakukan informan ini kemudian didukung dengan faktor lain yaitu lingkungan konsumen yang mayoritas juga menggunakan kosmetik halal sehingga semakin mendukung pemahaman mereka (meningkatkan kepercayaan) bahwa label halal pada kosmetik adalah sebagai salah satu bentuk untuk merepresentasikan agama Islam. Berikut ini akan dijelaskan dalam tabel mengenai tiga tahapan dalam konstruksi sosial terhadap konsumen muslim pengguna produk kosmetik berlabel halal.

Tabel 1 Tahapan Konstruksi Sosial Konsumen Muslim terhadap Labelling Halal Produk Kosmetik

\begin{tabular}{|l|l|}
\hline \multicolumn{1}{|c|}{ Tahapan } & \multicolumn{1}{|c|}{ Penjelasan } \\
\hline Eksternalisasi & \begin{tabular}{l} 
Berupa implikasi konsumen dari pemahaman ajaran \\
agama Islam yang diberikan oleh orang tuanya \\
dengan memilih dengan baik produk apapun yang \\
akan digunakan, termasuk memperhatikan label halal \\
yang tercantum pada produk karena secara tidak \\
langsung label halal digambarkan sebagai bentuk \\
representasi Islam. \\
\hline Objektifikasi
\end{tabular}$\quad \begin{array}{l}\text { Digambarkan dengan berubahnya pola perilaku } \\
\text { informan dalam memilih produk yaitu lebih selektif } \\
\text { lagi ketika akan membeli suatu produk termasuk }\end{array}$ \\
\hline
\end{tabular}




\begin{tabular}{|l|l|}
\hline \multicolumn{1}{|c|}{ Tahapan } & \multicolumn{1}{|c|}{ Penjelasan } \\
\hline & $\begin{array}{l}\text { lebih memperhatikan label halal (karena memiliki } \\
\text { nilai plus tersendiri), meskipun dalam prakteknya } \\
\text { belum sepenuhnya mereka membeli produk } \\
\text { kosmetik yang berlabel halal. }\end{array}$ \\
\hline Internalisasi & $\begin{array}{l}\text { Ditandai dengan pengaruh dari lingkungan teman } \\
\text { sebaya informan yang juga mendukung labelling } \\
\text { halal produk kosmetik ini. Dimana, keputusan } \\
\text { konsumen untuk memakai produk kosmetik halal } \\
\text { juga dikarenakan banyaknya teman-teman informan } \\
\text { yang memakai produk ini dan mereka sudah sangat } \\
\text { percaya terhadap kekuatan branding halal produk } \\
\text { tersebut karena perusahaan sudah memiliki nama } \\
\text { yang besar. }\end{array}$ \\
\hline
\end{tabular}

Dari tabel di atas, dapat diketahui bahwa konstruksi masyarakat terhadap labelling halal sesuai dengan teori konstruksi Peter L. Berger. Berger memiliki beberapa pendapat mengenai konstruksi yang dibangun masyarakat yaitu masyarakat membentuk suatu konstruksi berdasarkan realitas dalam lingkungan sosialnya, hasil dari pemikiran manusia sebagai bentuk dari dunia sosialnya akan terus berkembang, konstruksi akan membangun kehidupan masyarakat secara berkelanjutan dan dilakukan secara terus menerus, realitas dan pengetahuan masyarakat adalah dua hal yang berbeda sehingga pengetahuan masyarakat harus berimplikasi pada proses-proses yang telah dibangun sesuai dengan kenyataan (Berger dan Luckman, 1990 dalam Prasojo).

\section{KESIMPULAN}

Label halal yang tercantum pada produk kosmetik sangat penting kehadirannya bagi konsumen muslim, sehingga hal ini membuat konstruksi sosial yang terjadi pada pengguna produk kosmetik yang beragama muslim di Politeknik Negeri Malang. Konstruksi yang pertama yaitu bagi konsumen muslim produk kosmetik, label halal memiliki added value karena produk 
yang mereka gunakan aman dan terpercaya. Konsumen meyakinkan diri dan menghilangkan keraguan untuk memakai suatu produk kosmetik yang berlabel halal karena produk yang sudah memiliki sertifikasi halal memiliki 'nilai plus' bagi mereka yaitu rasa aman meningkatkan kenyamanan konsumen dalam menggunakan kosmetik halal. Konstruksi yang kedua yaitu label halal sebagai representasi simbolik Islam dalam kosmetik halal. Label halal adalah symbol Islam untuk mengatur umatnya bahwa tidak semua produk bisa mereka gunakan karena Islam memiliki kaidah tersendiri untuk menetapkan halal dan haramnya bahan-bahan sebagai kandungan utama dalam pembuatan produk kosmetik yang boleh digunakan pada tubuh ataupun tidak. Selain itu, konstruksi yang dibangun oleh konsumen muslim pengguna kosmetik berlabel halal ini sesuai dengan teori konstruksi oleh Peter L. Berger mengenai tiga tahapan konstruksi sosial yaitu eksternalisasi, objektifikasi, dan internalisasi.

\section{REKOMENDASI}

Pemerintah perlu lebih tegas dalam penetapan sertifikasi label halal untuk meminimalisir produk yang tidak layak untuk dijual pada konsumen. Bagi konsumen dan produsen, perlu adanya pemahaman yang lebih dalam lagi mengenai makna 'label halal' itu sendiri. Label halal bukan hanya digunakan sebagai labelisasi untuk mengikuti era sekarang yang sedang booming tentang nilai-nilai Islam. Penetapan label halal harus mengikuti tentang kaidah dan syariat yang sudah ditetapkan Islam agar tidak ada pihak yang dirugikan.

\section{DAFTAR PUSTAKA}

Alfian, Ian. Analisis Pengaruh Label Halal, Brand, dan Harga Terhadap Keputusan Pembelian di Kota Medan. Dari Jurnal UIN Sunan Ampel, (Online), (https://jurnal.uinsu.ac.id), diakses 10 Oktober 2019.

Addian, Andini. 2019. Fenomena Gerakan Hijrah di Kalangan Pemuda Muslim sebagai Mode Sosial. Dari Jurnal Unusa, (Online), (https://journal2.unusa.ac.id/index.php/JIC/article/view/1313/955), diakses 26 Februari 2020. 
Bulan, T. P. L. (2016). Pengaruh Labelisasi Halal terhadap Keputusan Pembelian Sosis di Kuala Simpang Kabupaten Aceh Tamiang. Jurnal Manajemen Dan Keuangan, 5(1), 431-439. Retrieved from https://ejurnalunsam.id/index.php/jmk/article/view/49

BPS Kota Malang. 2019. Presentase Penduduk Kota Malang Menurut Jenis Kelamin 2010-2020. Dari BPS Kota Malang, (Online), (https://malangkota.bps.go.id/), diakses 6 Oktober 2019.

Budy, Viva. 2019. Indonesia, Negara dengan Penduduk Muslim Terbesar Dunia. Dari Katadata, (Online), (https://databoks.katadata.co.id/), diakses 5 Oktober 2019.

Cahyono, Afiq Dwi. 2016. Urgensi Penerapan Sertifikasi Halal Majelis Ulama Indonesia (MUI) terhadap Produk UMKM (Studi Kasus Kota Mataram). Dari Jurnal Unram, (Online), (http://eprints.unram.ac.id/9421/1/jurnal\%20 ilmiah.pdf) , diakses 25 Februari 2020.

Fajriani, Suci. 2019. Hijrah Islami Milenial Berdasarkan Paradigma Berorientasi Identitas. Dari Jurnal Unpad (Online), (http://jurnal.unpad.ac.id/), diakses 5 Oktober 2019.

Ritzer, George. 2017. Teori Sosiologi: Dari Teori Sosiologi Klasik Sampai Perkembangan Mutakhir Teori Sosial Postmodern. Bantul: Kreasi Wacana.

Ibrohim, B. 2016. Memaknai Momentum Hijrah. Dari Jurnal UIN Banten, (Online), (https://www.google.com/), diakses 6 Oktober 2019.

Ilyas, Musyfikah. 2018. Sertifikasi dan Labelisasi Halal Perspektif Maslahat. Dari Jurnal UIN Alauddin Makasar, (Online), (http://journal.uin- alauddin.ac.id/), diakses 6 Oktober 2019.

Izzudin, Ahmad. 2018. Pengaruh Label Halal, Kesadaran Halal, dan Bahan Makanan terhadap Minat Beli Makanan Kuliner. Dari Jurnal Unmuh Jember, (Online), (http://jurnal.unmuhjember.ac.id/index.php/ PENELITIAN_IPTEKS/ article/view/1886), diakses 25 Februari 2020.

KBBI. 2012-2019. Arti Kata Representasi. Dari KBBI, (Online), (https://kbbi.web.id/representasi), diakses 22 Oktober 2019. 
Khomariyah, Nurul. 2016. Pengaruh Kesadaran Halal, Islamic Branding, dan Product Ingredients Terhadap Minat Beli Produk Luwak White Coffee (Studi Pada Masyarakat Desa Putatsewu, Jatitengah, Sukodono, Sragen). Dari Jurnal IAIN Surakarta, (Online), (http://eprints.iain-surakarta.ac.id/), diakses 6 Oktober 2019.

Moleong, J. 2013. Metode Penelitian Kualitatif. Bandung: PT Remaja Rosdakarya.

Muhammad, Muhammad. 2009. Label Halal dan Spiritualitas Bisnis Interpretasi atas Bisnis Home Industry. Dari Jurnal UMM, (Online), (http://ejournal.umm.ac.id/index.php/salam/article/view/446), diakses 25 Februari 2020.

Muslimah, Siti. 2017. Label Halal Pada Produk Pangan Kemasan dalam Perspektif Perlindungan Konsumen Muslim. Dari Jurnal UNS, (Online), (https://jurnal.uns.ac.id/yustisia/article/view/10630/9508), diakses 25 Februari 2020.

Nugraha, Ranu. 2017. Pengaruh Labelisasi Halal Terhadap Minat Beli Konsumen (Survei Pada Mahasiswa Muslim Konsumen Mie Samyang yang Berlogo Halal Korean Muslim Federation di Kota Malang). Dari Jurnal UB, (Online), (http://administrasibisnis. studentjournal.ub.ac.id/), diakses 6 Oktober 2019.

Nofri, Okta. 2018. Analisis Perilaku Konsumen dalam Melakukan Online Shopping di Kota Makassar. Dari Jurnal UIN Alauddin Makassar, (Online), (www.journal.uin-alauddin.ac.id), diakses 10 Oktober 2019.

Poloma, Margaret. 2010. Sosiologi Kontemporer. Jakarta: PT Raja Grafindo Persada.

Prasojo, M. Nur. 2015. Konstruksi Sosial Masyarakat Terhadap Alam Gunung Merapi. Dari Jurnal Analisa Sosiologi UNS, (Online), (https://jurnal.uns.ac.id), diakses 5 Desember 2019.

Putri, Tengku. 2016. Pengaruh Labelisasi Halal terhadap Keputusan Pembelian Sosis di Kuala Simpang Kabupaten Aceh Tamiang Dari Jurnal Universitas Samudra, (Online), (www.ejurnalunsam.ac.id), diakses 6 Oktober 2019. 
Ratri, Nurlayla. 2019. BPS: Kota Malang Saat Ini Sama dengan Jakarta Lima Tahun Lalu. Dari Malangtimes.com, (Online), (https://www.malangtimes.com/), diakses 6 Oktober 2019.

Ramadhani, Atika. 2016. Pengaruh Gaya Hidup, Label Halal, Dan Harga Terhadap Keputusan Pembelian Kosmetik Wardah Pada Mahasiswa Program Studi Manajemen Fakultas Ekonomi Universitas Medan Area Medan. Dari Academia, (Online), (https://www.academia.edu), diakses 14 November 2019.

Sari, Annisa. 2018. Perilaku Komunikasi Pelaku Hijrah. Dari Jurnal Unpas, (Online), (https://journal.unpas.ac.id/), diakses 6 Oktober 2019.

Tunardy, Wibowo. 2016. Pengertian Konsumen serta Hak dan Kewajiban Konsumen. Dari Jurnal Hukum, (Online), (https://www.jurnalhukum.com/), diakses 10 Oktober 2019.

Vanany, I., Soon, J., Maryani, A. and Wibawa, B. (2019), "Determinants of halal-food consumption in Indonesia", Journal of Islamic Marketing, Vol. ahead-of-print No. ahead-of-print. https://doi.org/10.1108/ JIMA-09-2018-0177

Widyaningrum, P. (2017). Pengaruh Label Halal dan Celebrity Endorser terhadap Keputusan Pembelian (Survei pada Konsumen Wardah di Ponorogo). JESI (Jurnal Ekonomi Syariah Indonesia), 6(2), 83-98. doi:http://dx.doi.org/10.21927/jesi.2016.6(2).\%p 